\title{
Transgenic Mice Expressing Green Fluorescent Protein under the Control of the Melanocortin-4 Receptor Promoter
}

\author{
Hongyan Liu, ${ }^{1 \star}$ Toshiro Kishi, ${ }^{2 *}$ Aaron G. Roseberry, ${ }^{1}$ Xiaoli Cai, ${ }^{1}$ Charlotte E. Lee, ${ }^{3}$ Jason M. Montez, ${ }^{1}$ \\ Jeffrey M. Friedman, ${ }^{1}$ and Joel K. Elmquist ${ }^{2,3}$ \\ ${ }^{1}$ Laboratory of Molecular Genetics, Howard Hughes Medical Institute, The Rockefeller University, New York, New York 10021, ${ }^{2}$ Department of Neurology, \\ Beth Israel Deaconess Medical Center, and Program in Neuroscience, Harvard Medical School, Boston, Massachusetts 02215, and ${ }^{3}$ Department of Medicine \\ and Division of Endocrinology, Beth Israel Deaconess Medical Center, Harvard Medical School, Boston, Massachusetts 02215
}

The melanocortin-4 receptor (MC4-R) is an important regulator of energy homeostasis, and evidence suggests that MC4-R-expressing neurons are downstream targets of leptin action. MC4-Rs are broadly expressed in the CNS, and the distribution of MC4-R mRNA has been analyzed most extensively in the rat. However, relatively little is known concerning chemical profiles of MC4-R-expressing neurons. The extent to which central melanocortins act presynaptically or postsynaptically on MC4-Rs is also unknown. To address these issues, we have generated a transgenic mouse line expressing green fluorescent protein (GFP) under the control of the MC4-R promoter, using a modified bacterial artificial chromosome. We have confirmed that the CNS distribution of GFP-producing cells is identical to that of MC4-R mRNA in wild-type mice and that nearly all GFP-producing cells coexpress MC4-R mRNA. For example, cells coexpressing GFP and MC4-R mRNA were distributed in the paraventricular hypothalamic nucleus (PVH) and the dorsal motor nucleus of the vagus (DMV). MC4-R promotor-driven GFP expression was found in PVH cells producing thyrotropin-releasing hormone and in cholinergic DMV cells. Finally, we have observed that a synthetic MC3/4-R agonist, MT-II, depolarizes some GFP-expressing cells, suggesting that MC4-Rs function postsynaptically in some instances and may function presynaptically in others. These studies extend our knowledge of the distribution and function of the MC4-R. The transgenic mouse line should be useful for future studies on the role of melanocortin signaling in regulating feeding behavior and autonomic homeostasis.

Key words: MC4-R; transgenic mouse; electrophysiological recording; GFP; TRH; CRH; oxytocin; GAD67; choline acetyltransferase

\section{Introduction}

The melanocortin-4 receptor (MC4-R) regulates food intake and body weight in rodents and humans (Butler and Cone, 2002). This G-protein-coupled receptor is expressed widely in the CNS (Mountjoy et al., 1994; Kishi et al., 2003). Genetic evidence demonstrates that MC4-R blockade produces obesity syndromes. For example, obesity in Ay mice results from ectopic expression of agouti protein in the brain, which is an endogenous antagonist for melanocortin receptors including the MC4-R (Spiegelman and Flier, 1996; Fan et al., 1997; Graham et al., 1997; Ollmann et al., 1997). MC4-R -/- mice (Huszar et al., 1997) and humans (Vaisse et al., 1998; Farooqi et al., 2000) display a similar obesity syndrome. Transgenic overexpression of agouti-related protein (AgRP), another endogenous MC3/4-R antagonist, also results in obesity (Graham et al., 1997; Ollmann et al., 1997). Proopiomelanocortin (POMC) is the precursor of $\alpha-\mathrm{MSH}$, an en-

Received March 18, 2003; revised June 9, 2003; accepted June 13, 2003.

This work was supported by National Institutes of Health Grants DK56116, DK53301, and MH61583 to T.K. and J.K.E. We thank Dr. Andrew Cubitt from Aurora Bioscience for the Sapphire DNA, Dr. Nathaniel Heintz and Xiangdong Yang for the shuttle vector PSV1, Dr. Stanley J. Watson for the AVP and CRH probes, and Dr. Rexford S. Ahima for the TRH probe.

*H.L. and T.K. contributed equally to this work.

Correspondence should be addressed to Dr. Jeffrey M. Friedman, Box 305, Howard Hughes Medical Institute, The Rockefeller University, 1230 York Avenue, New York, NY 10021. E-mail: friedj@mail.rockefeller.edu.

Copyright $\odot 2003$ Society for Neuroscience $\quad$ 0270-6474/03/237143-12\$15.00/0 dogenous MC3/4-R agonist, and POMC-null mice (Yaswen et al., 1999) and humans (Krude et al., 1998) also exhibit an obese phenotype.

A large body of evidence has shown that leptin (Zhang et al., 1994; Friedman and Halaas, 1998; Saper et al., 2002) stimulates melanocortin signaling. The arcuate nucleus of the hypothalamus (Arc) has been established as a site of leptin action in the CNS. The Arc contains two counterpoised neuronal populations producing distinct melanocortins, i.e., $\alpha$-MSH and AgRP (Broberger et al., 1998a; Elias et al., 1998). $\alpha$-MSH and AgRP neurons coexpress the signaling or long-form leptin receptor (Mercer et al., 1996; Cheung et al., 1997). Leptin has been shown to increase POMC mRNA (Schwartz et al., 1997; Thornton et al., 1997; Mizuno et al., 1998). In contrast, AgRP mRNA is increased during fasting when leptin levels rapidly fall and in leptin-deficient ob/ob mice, and its expression is reduced by exogenous leptin (Hahn et al., 1998). Leptin-induced anorexia can be suppressed by melanocortin receptor antagonism (Seeley et al., 1997), and MC4-R antagonists also block leptin-induced increases of uncoupling protein-1 in brown adipose tissue of fasted rats (Scarpace et al., 1997; Kotz et al., 1998; Satoh et al., 1998). Finally, the thyrotropin-releasing hormone (TRH) gene is transcriptionally regulated by leptin and melanocortins (Harris et al., 2001; Fekete et al., 2000). Taken together, these observations suggest that subsets of MC4-R-expressing neurons mediate some of the leptin 
actions on autonomic and endocrine responses, and on feeding behavior. Importantly, leptin-independent melanocortin signaling pathways also exist (Boston et al., 1997; Butler et al., 2001).

However, despite the established importance of the MC4-R, relatively little is known regarding chemical and electrophysiological profiles of MC4-R-expressing cells. In addition, neuroanatomic studies of the MC4-R have been limited by the lack of high-affinity antibodies. To address these issues, we generated a transgenic mouse line in which green fluorescent protein (GFP) is expressed under the control of the MC4-R promoter, by using a modified bacterial artificial chromosome (Yang et al., 1997). The characteristics of this mouse line and the MC4-R-expressing cells are described in detail below.

\section{Materials and Methods}

Production of the MC4R-Tau-Sapphire transgenic (MC4-R/GFP) mouse. Sapphire is a blue-shifted GFP variant from Aurora Biosciences (La Jolla, CA). Bacterial artificial chromosome (BAC) filters (BAC mouse II) and clones were obtained from Genome Systems (St. Louis, MO). TauSapphire fusion protein and polyA signal were inserted into the ATG site of a MC4-R-containing BAC using a method developed by Yang et al. (1997) to modify BAC in Escherichia coli host bacterial. Kozak sequence was added before Tau, a microtubule-binding protein (Callahan and Thomas, 1994). PolyA signal was PCR amplified from nucleotide 6971088 of SV40 polyA of pREP7 (Invitrogen, Carlsbad, CA). The modification of the BAC requires a shuttle vector (PSV1) that has three features: a temperature-sensitive origin of replication, a $\operatorname{Rec} A$ gene to introduce recombination in a recombination-deficient $E$. coli host, and a tetracycline resistance gene (Tet+). The shuttle vector has $2.5 \mathrm{~kb}$ and $1.7 \mathrm{~kb}$ arms of MC4-R sequence flanking Tau-Sapphire polyA sequence. The shuttle vector was transformed into the DH10B E. coli host harboring the MC4-R BAC. After two homologous recombination events, the modified MC4-R BAC was selected by temperature and antibiotic sensitivity. The homologous recombination of the modified BAC was confirmed through Southern analysis. The BAC DNA was then purified with Cesium chloride gradient, linearized with NotI, further purified with Sepharose CL-4b (Sigma, St. Louis, MO) column, and injected into pronuclei of CBA/C57B16 F1 mice by the Rockefeller transgenic facility. The incorporation of the transgene in mouse genome was identified through Southern blots and PCR. The genotyping primers for the transgene is GFPF1 5'-CCGAGGATCCTACCATGGTGAGCAAGGGCGA-3' and GFP407R 5' -CAGCTTGTGCCCCAGGATGT.

Animals and histology. The MC4-R/GFP mice and C57BL/6 mice (25-35 gm; Jackson Laboratory, Bar Harbor, ME) were housed with food and water available ad libitum in a light-controlled (12 hr light/dark cycle; lights on 7 A.M.) and temperature-controlled $\left(21.5-22.5^{\circ} \mathrm{C}\right)$ environment. The animals and procedures used in this study were in accordance with the guidelines of The Rockefeller Animal Research Center as well as with the guidelines and approval of the Harvard Medical School and Beth Israel Deaconess Medical Center Institutional Animal Care and Use Committees. Mice were deeply anesthetized with intraperitoneal injection of chloral hydrate $(350 \mathrm{mg} / \mathrm{kg}$ ) and perfused transcardially with DEPC-treated $0.9 \%$ saline, followed by $50 \mathrm{ml}$ of $10 \%$ neutral buffered formalin. Brains were removed, stored in the same fixative for $4 \mathrm{hr}$ at $4^{\circ} \mathrm{C}$, immersed in $20 \%$ sucrose in DEPC-treated PBS, pH 7.0, at $4^{\circ} \mathrm{C}$ overnight, and were cut coronally at $25 \mu \mathrm{m}$ into $1: 5$ equal series on a freezing microtome. Sections were stored at $-20^{\circ} \mathrm{C}$ in an antifreeze solution (Simmons et al., 1989) until sections were treated for immunohistochemistry (IHC) and/or in situ hybridization histochemistry (ISHH).

IHC for GFP. To determine GFP-producing brain sites, IHC was performed using seven mice (four mice of line 21; three mice of line 30), as reported previously (Elmquist and Saper, 1996; Elias et al., 1998). Sections were pretreated with $0.3 \%$ hydrogen peroxide in PBS, pH 7.4, for 30 $\mathrm{min}$ at room temperature and then incubated in 3\% normal donkey serum (Jackson ImmunoResearch Laboratories Inc., West Grove, PA) with $0.25 \%$ Triton X-100 in PBS (PBT) for $1 \mathrm{hr}$, followed by overnight incubation in a GFP rabbit primary antiserum (Molecular Probes, Eu- gene, OR; 1:20,000 in PBT) at room temperature. After washing in PBS, sections were incubated in biotinylated donkey anti-rabbit IgG (Jackson ImmunoResearch Laboratories Inc.; 1:1,000) for $1 \mathrm{hr}$ at room temperature and then incubated in a solution of $\mathrm{ABC}$ (Vectastain Elite ABC Kit; Vector Laboratories, Burlingame, CA; 1:500) dissolved in PBS for $1 \mathrm{hr}$. After washing in PBS, the sections were incubated in a solution of $0.04 \%$ DAB (Sigma) and $0.01 \%$ hydrogen peroxide dissolved in PBS. Brain sections were mounted onto gelatinized slides, air-dried, dehydrated in ascending concentrations of ethanol, cleared in xylenes, and were then coverslipped with Permaslip (Alban Scientific, St. Louis, MO). GFPimmunoreactive (GFP-IR) cells were plotted using a camera lucida attached to a microscope (Zeiss Axioscope). Coverslips were then removed, and the sections were conterstained with thionin to determine nuclear boundaries (Kishi et al., 2000).

Single-label ISHH for MC4-R. To examine the distribution of MC4-R mRNA in the wild-type (WT) mouse brain, single-label ISHH was performed as reported recently from our laboratory (Marcus et al., 2001; Kishi et al., 2003), based on a modification of the protocol previously reported by our and other laboratories (Simmons et al., 1989; Chan et al., 1993; Brady et al., 1994; Ericsson et al., 1995; Elmquist et al., 1998; Elias et al., 1999). Tissue sections were mounted onto SuperFrost slides (Fisher Scientific, Pittsburgh, PA), air-dried, and stored in desiccated boxes at $-20^{\circ} \mathrm{C}$. Before hybridization, sections were fixed in $4 \%$ formaldehyde in DEPC-treated PBS, pH 7.0, for $20 \mathrm{~min}$ at $4^{\circ} \mathrm{C}$, dehydrated in ascending concentrations of ethanol, cleared in xylenes for $15 \mathrm{~min}$, rehydrated in descending concentrations of ethanol, and placed in prewarmed sodium citrate buffer $\left(95-100^{\circ} \mathrm{C}\right.$; pH 6.0). Slides were then placed in a Sharp (Nahwah, NJ) R-510C commercial microwave oven $(1100 \mathrm{~W})$ for $10 \mathrm{~min}$ at $70 \%$ power (temperature, $95-100^{\circ} \mathrm{C}$ ), dehydrated in ascending concentrations of ethanol, and air-dried.

The MC4-R probe was made using a DNA fragment corresponding to nucleotides 806-1400 of the rat MC4R transcript (Kishi et al., 2003). BLAST sequence alignment indicates $89 \%$ identity between the rat sequence and nucleotides 665-999 of the mouse MC4-R transcript (GenBank accession number NM_016977). To generate antisense ${ }^{35}$ S-labeled cRNA, the plasmids were linearized by digestion with $\mathrm{NcoI}$ and subjected to in vitro transcription with SP6 RNA polymerase according to the manufacturer's protocol (Promega, Madison, WI). For generation of sense ${ }^{35}$ S-labeled cRNA, the plasmids were linearized by digestion with SalI and subjected to in vitro transcription with T7 RNA polymerase according to the manufacturer's protocol (Ambion, Austin, TX). The ${ }^{35} \mathrm{~S}$ labeled cRNA probe for the MC4-R mRNA was then diluted to $10^{6}$ $\mathrm{cpm} / \mathrm{ml}$ in a hybridization solution composed of $50 \%$ formamide, $10 \mathrm{~mm}$ Tris-HCl (Gibco-BRL, Bethesda, MD), pH 8.0, 5.0 mg of tRNA (Invitrogen), 10 mм DTT, $10 \%$ dextran sulfate, $0.3 \mathrm{M} \mathrm{NaCl}, 1$ mм EDTA, pH 8.0, and $1 \times$ Denhardt's solution (Sigma).

Hybridization solution and a coverslip were applied to each slide, and sections were incubated for $12-16 \mathrm{hr}$ at $57^{\circ} \mathrm{C}$. Coverslips were then removed, and slides were washed with $2 \times$ SSC, pH 7.0. Sections were then incubated in $0.002 \%$ RNAase A (Roche Molecular Biochemicals, Indianapolis, IN) with $0.5 \mathrm{M} \mathrm{NaCl}, 10 \mathrm{~mm}$ Tris-HCl, $\mathrm{pH}$ 8.0, and $1 \mathrm{~mm}$ EDTA for $30 \mathrm{~min}$. Subsequently, sections were washed in decreasing concentrations of SSC containing $0.25 \%$ DTT: $2 \times$ SSC at $50^{\circ} \mathrm{C}$ for $1 \mathrm{hr}, 0.2 \times$ SSC at $55^{\circ} \mathrm{C}$ for $1 \mathrm{hr}$, and $0.2 \times \mathrm{SSC}$ at $60^{\circ} \mathrm{C}$ for $1 \mathrm{hr}$. Sections were next dehydrated in graded ethanol $(50,70,80$, and $90 \%)$ containing $0.3 \mathrm{M}$ $\mathrm{NH}_{4} \mathrm{OAc}$, followed by $100 \%$ ethanol. Slides were air-dried and placed in $\mathrm{x}$-ray film cassettes with BMR-2 film (Kodak, Rochester, NY) for 2-3 d. Slides were then dipped in NTB2 photographic emulsion (Kodak), dried, and stored in desiccated and foil-wrapped boxes at $4^{\circ} \mathrm{C}$ for 3-4 weeks. Finally, slides were developed with D-19 developer (Kodak), counterstained with thionin, dehydrated in graded ethanols, cleared in xylenes, and coverslipped with Permaslip.

In a WT mouse, an adjacent series of sections was stained with thionin to identify nuclear boundaries (Marcus et al., 2001; Kishi et al., 2003). Control experiments to confirm the specificity of this protocol included hybridization with sense probes and with antisense probes after treatment with RNAase A $(200 \mu \mathrm{g} / \mathrm{ml})$.

Dual-label ISHH/IHC. IHC was coupled with free-floating ISHH to demonstrate cells coexpressing GFP and MC4-R mRNA in three mice of 
line 21 as well as in two mice of line 30 . The procedure was a modification of that described previously (Priestley et al., 1993; Elias et al., 1998; Yamamoto et al., 2003). Brain sections were first rinsed in DEPC-treated PBS, pH 7.0, and were pretreated with $1 \%$ sodium borohydride (Sigma) in DEPC-PBS for $15 \mathrm{~min}$ at room temperature. After washing in DEPCPBS, sections were rinsed in $0.1 \mathrm{M}$ TEA, $\mathrm{pH} 8.0$, and incubated in $0.25 \%$ acetic anhydride in $0.1 \mathrm{~m}$ TEA for $10 \mathrm{~min}$. After washing in $2 \times$ SSC, sections were incubated in the above-mentioned hybridization solution containing the MC4-R probes diluted to $10^{6} \mathrm{cpm} / \mathrm{ml}$ for $12-16 \mathrm{hr}$ at $57^{\circ} \mathrm{C}$. Subsequently, sections were rinsed in $4 \times$ SSC and incubated in $0.002 \%$ RNAase A (Roche Molecular Biochemicals) with $0.5 \mathrm{M} \mathrm{NaCl}, 10$ $\mathrm{mm}$ Tris- $\mathrm{HCl}, \mathrm{pH} 8$, and $1 \mathrm{~mm}$ EDTA for $30 \mathrm{~min}$ at $37^{\circ} \mathrm{C}$. Sections were rinsed with $2 \times \mathrm{SSC}$ and then with $50 \%$ formamide in $0.2 \times \mathrm{SSC}$ at $50^{\circ} \mathrm{C}$. Subsequently, sections were washed in decreasing concentrations of SSC: $2 \times \mathrm{SSC}$ at $50^{\circ} \mathrm{C}$ for $1 \mathrm{hr}, 0.2 \times \mathrm{SSC}$ at $55^{\circ} \mathrm{C}$ for $1 \mathrm{hr}$, and $0.2 \times \mathrm{SSC}$ at $60^{\circ} \mathrm{C}$ for $1 \mathrm{hr}$. After washing in PBS, pH 7.4, IHC for GFP was performed as described above. Sections were mounted onto SuperFrost slides (Fisher Scientific) and were placed in x-ray film cassettes with BMR-2 film (Kodak) for 2-3 d. Slides were then treated as described above without counterstaining.

GFP-expressing cells were chemically defined using the same duallabel free-floating ISHH/IHC method with antisense probes for corticotropin-releasing hormone (CRH) (Day et al., 2002), arginine vasopressin (AVP) (Helmreich et al., 1999), orexin (ORX) (Sakurai et al., 1998), melanin-concentrating hormone (MCH) (Qu et al., 1996), GAD67 (Erlander et al., 1991), or ChAT (Kishi et al., 2003). An antisense for TRH was also used, which was made by using a DNA fragment corresponding to nucleotides $308-573$ of the mouse preproTRH mRNA (GenBank accession number X59387; a gift from Dr. Rexford S. Ahima, Department of Medicine, Division of Endocrinology, University of Pennsylvania School of Medicine, Philadelphia, PA). In addition, an antisense probe for oxytocin was applied, which was generated by using a DNA fragment corresponding to nucleotides 3060-3256 of the rat oxytocin DNA (GenBank accession number X12792). Three transgenic mice were used in each dual-label experiment. The ${ }^{35}$ S-labeled cRNA probes were generated from the cDNA templates by in vitro transcription with appropriate polymerases (SP6 for oxytocin, AVP, MCH, GAD67, ChAT, and TRH; T7 for CRH and ORX) according to the manufacturers' protocol (Promega; Ambion). The period during which slides were exposed to emulsion ranged from 3 to $10 \mathrm{~d}$.

Two methods of scoring double-labeled cells were used (Elias et al., 1999). The less stringent of the two considered cells to contain positive hybridization if the silver grains overlying GFP-IR cell bodies were fivefolds above background hybridization levels. Estimates of background hybridization levels were made by calculating the mean number of silver grains overlying a counting grid $\left(100 \mu \mathrm{m}^{2}\right)$ in the internal capsule. A more conservative estimate was used that defined cells as double-labeled only if the silver grains above background conformed to the shape of the GFP-IR cell bodies.

Anatomic analysis and production of photomicrographs. Sections were analyzed with a Zeiss Axioskop or a Zeiss Stemi 2000-C dissecting microscope. Cytoarchitectonic details were added by using a camera lucida. Photomicrographs were produced with a Spot digital camera (Diagnostic Instruments, Sterling Heights, MI) attached to the microscopes and an Apple Macintosh G3 computer. An image editing software (Adobe Photoshop 5.5) was used to combine microphotographs onto plates, and figures were printed on a dye sublimination printer (Kodak 8670 PS). Only the contrast and brightness were adjusted.

Electrophysiological recording. Young MC4-R/GFP mice (4-6 weeks of age; line 21) were deeply anesthetized with halothane (Halocarbon, River Edge, $\mathrm{NJ}$ ) before decapitation and removal of the entire brain. The brain was immediately submerged in ice-cold, carbogen-saturated $\left(95 \% \mathrm{O}_{2} /\right.$ $5 \% \mathrm{CO}_{2}$ ) artificial CSF (aCSF), and a brain block containing the hypothalamus was made. The aCSF contained (in $\mathrm{mm}$ ): $126 \mathrm{NaCl}, 2.5 \mathrm{KCl}, 2.4$ $\mathrm{CaCl}_{2}, 1.2 \mathrm{NaH}_{2} \mathrm{PO}_{4}, 1.2 \mathrm{MgCl}_{2}, 21.4 \mathrm{NaHCO}_{3}$, and 11.1 glucose. Coronal sections $(180 \mu \mathrm{m})$ were cut with a Leica VT1000S vibratome, and the slices were incubated at $37^{\circ} \mathrm{C}$ for $\sim 30 \mathrm{~min}$, followed by incubation at room temperature until used.

Slices were transferred to the recording chamber and allowed to equil- ibrate for 10-20 min before use. The slices were perfused with oxygenated aCSF $\left(29-30^{\circ} \mathrm{C}\right)$ at a flow rate of $\sim 1.7 \mathrm{ml} / \mathrm{min}$. GFP-positive MC4-R cells in the paraventricular hypothalamic nucleus (PVH) and the dorsomedial nucleus (DMH) were visualized using epifluorescence and infrared-differential interference contrast (IR-DIC) imaging on an upright Zeiss Axioskop 2FS Plus microscope equipped with filter sets specific for Sapphire GFP (excitation, 395; emission, 510; Chroma Technology Corp., Brattleboro, VT) and a Sony XC-75 CCD camera. MC4-R neurons were identified via epifluorescence and then patched under IRDIC optics. Recordings were performed using a potassium gluconatebased internal solution, which contained (in mM): 128 KGluconate, 10 HEPES, 1 EGTA, $10 \mathrm{KCl}, 1 \mathrm{MgCl}_{2}, 0.3 \mathrm{CaCl}_{2}, 5 \mathrm{MgATP}$, and $0.3 \mathrm{NaGTP}$, $\mathrm{pH} 7.35$, with $\mathrm{KOH}$. Electrodes were borosilicate glass and had resistances of $\sim 2.5-4 \mathrm{M} \Omega$ when filled with the KGluconate internal solution, and series resistance values were $<10 \mathrm{M} \Omega$ and were not compensated. Trials were excluded if the series resistance increased significantly during the experiment. Recordings were made using a HEKA EPC9/2 amplifier under the control of Pulse software. In addition, a Powerlab 4/20 using Chart software was used for data acquisition during current-clamp recordings. Data analysis was performed using PulseFit, Chart, IgorPro, and Microsoft Excel, and figures were created using PulseFit and IgorPro. Mean values for membrane potential were similar after analysis with
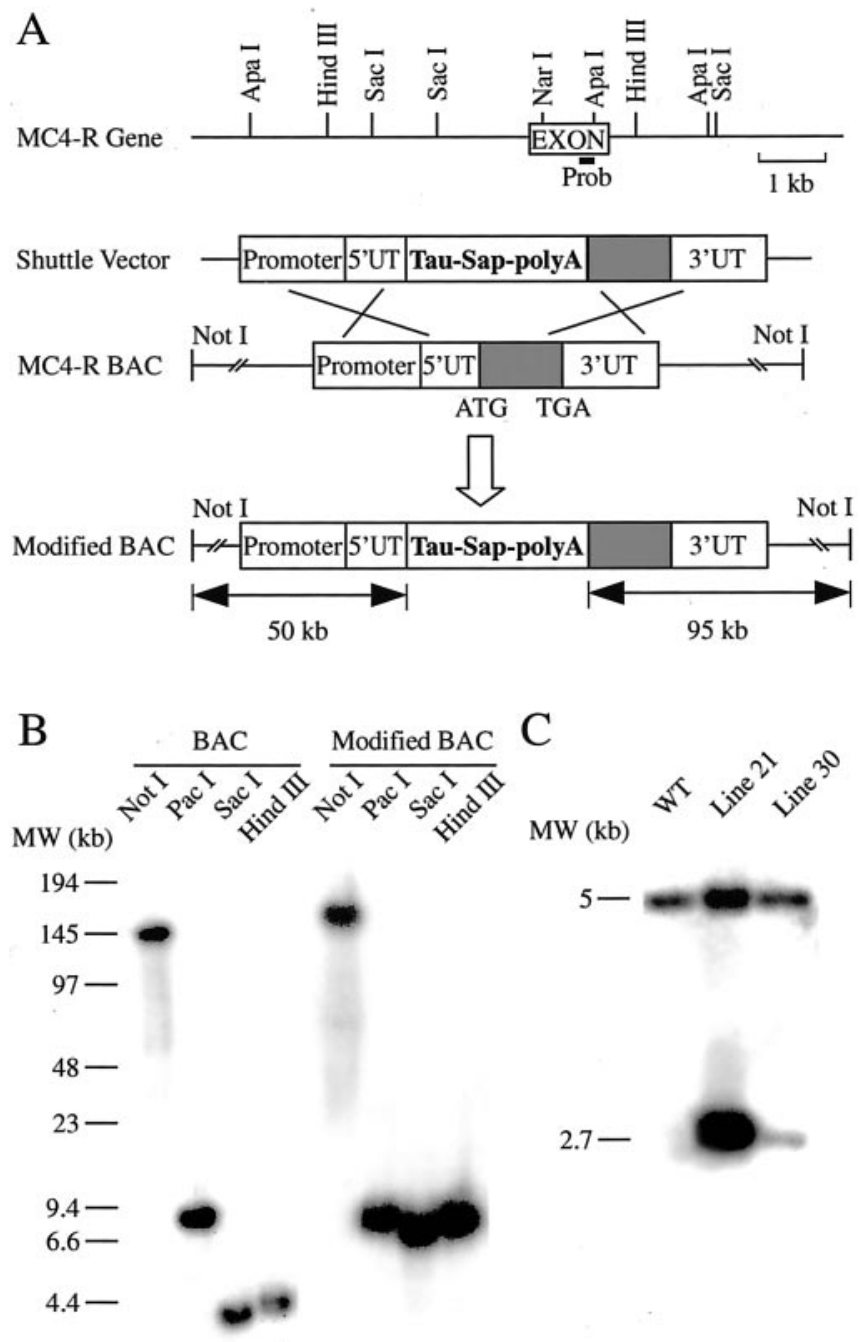

Figure 1. Production of MC4-R/GFP transgenic mice. $A$, Schematic drawings show insertion of Tau-Sapphire-polyA into the MC4-R BAC by homologous recombination in $E$. coli cells. $B$, Southern blot of pulsed field gel electrophoresis of restriction digestion of WT and modified MC4-R BAC. C, Southern blot analysis of Apal digest of genomic DNA from WT, line 21, and line 30 transgenic mice. 
A
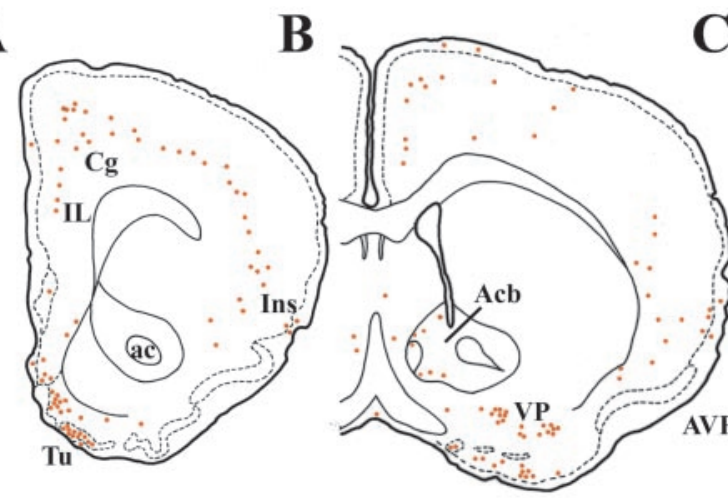

E

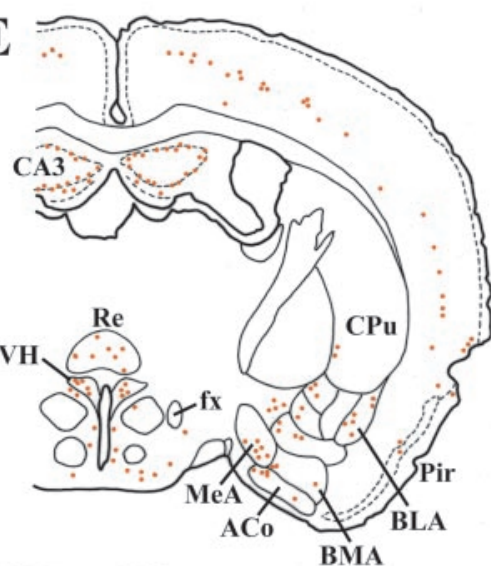

$\mathbf{H}$
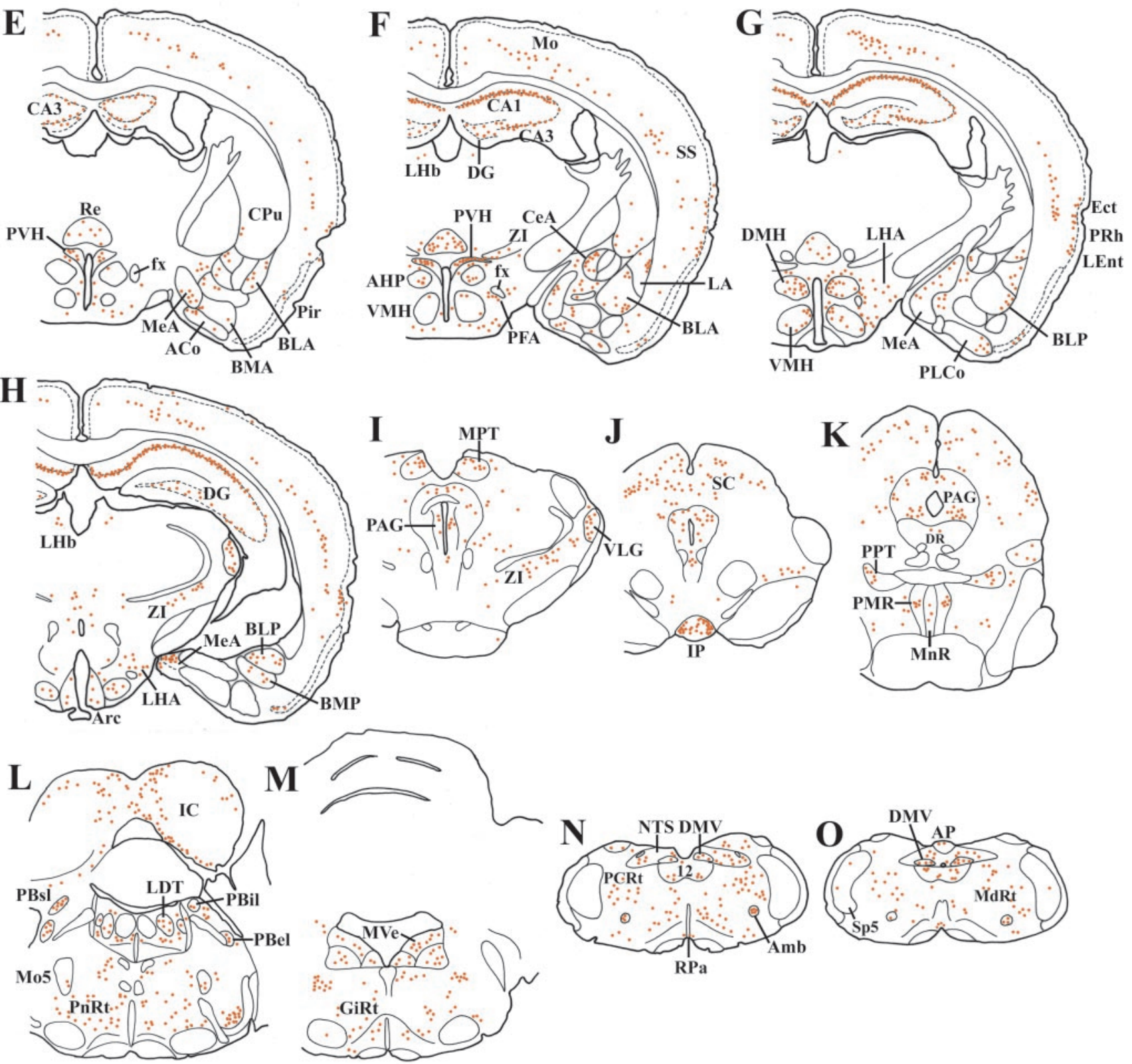

RPa

Figure 2. A series of line drawings showing the distribution of GFP-IR cells in the MC4-R/GFP mice (line 21). Brain sections are arranged in a rostral-to-caudal manner ( $A-0)$. Each red dot indicates approximately three GFP-IR cells. ac, Anterior commissure; Acb, nucleus accumbens; ACo, anterior cortical nucleus of the amygdala; AHi, amygdalohippocampal transition area; AHP, anterior hypothalamic nucleus, posterior; alv, alveus; Amb, nucleus ambiguus; AP, area postrema; APir, amygdalopiriform transition area; Aq, aqueduct; Arc, arcuate nucleus of the hypothalmus; AVPV, anteroventral periventricular nucleus; BLA, basolateral nucleus of the amygdala, anterior; BLP, basolateral nucleus of the amygdala, posterior; BMA, basomedial nucleus of the amygdala, anterior; BMP, basomedial nucleus of the amygdala, posterior; BST, bed nucleus of the stria terminalis; CA1-3, hippocampal fields; cc, central canal; CeA, central nucleus of the amygdala; C $\mathrm{g}$, cingulate cortex; (Pu, caudate-putamen; DG, dentate gyrus; DMH, dorsomedial nucleus of the hypothalamus; DMV, dorsal motor nucleus of the vagus; DR, dorsal raphe; Ect, ectorhinal cortex; fx, fornix; GiRt, gigantocellular reticular nucleus; HDB, nucleus of the diagonal band, horizontal limb; IC, inferior colliculus; IL, infralimbic cortex; Ins, insular cortex; IP, interpeduncular (Figure legend continues.) 
both Chart and Pulse, and the data reported here were obtained using Chart. All $p$ values reported were from paired $t$ tests.

\section{Results}

\section{Generation of MC4-R/GFP transgenic mice}

MC4-R BACs were isolated from a mouse BAC genomic library (Genome Systems), and the ATG site of the MC4-R gene was mapped. We chose one of the two BACs for modification based on the amount of $5^{\prime}$ and $3^{\prime}$ sequence contained in it. As shown in Figure $1 A$, this MC4-R BAC contains $50 \mathrm{~kb}$ of $5^{\prime}$ sequence and 95 $\mathrm{kb}$ of $3^{\prime}$ sequence relative to the ATG start site. After homologous recombination in E. coli, Tau-Sapphire-polyA was inserted into the ATG site of the BAC. Sapphire is a blue shifted variant of the GFP. We used a Tau-Sapphire fusion protein because earlier studies using $\beta$-galactosidase showed that Tau transported $\beta$-galactosidase into the axon facilitating studies of axonal projection (Callahan and Thomas, 1994). Enzymatic digestion of WT BAC and the modified BAC confirmed the correct insertion of Tau-Sapphire-polyA (Fig. $1 B$ ). The number and position of the restriction fragments were as expected, and no other rearrangement of the BAC besides the insertion of Tau-SapphirepolyA was detected. After pronuclear injection of the modified BAC, two lines (line 21 and line 30) of transgenic mice were generated. Line 21 has five copies of the modified BAC incorporated as determined by Southern blot of genomic DNA (Fig. 1C), whereas line 30 has one copy of the BAC. As expected, GFP fluorescence in line 21 is brighter than in line 30 . The distribution of GFP-IR cells in these two lines is described in detail below, followed by data showing colocalization of GFP-IR with MC4-R RNA as assessed using ISHH.

\section{Distribution of GFP-IR cells in line 21}

IHC for GFP was performed as described. Unless noted otherwise, the nomenclature used corresponds to the description in the mouse brain atlas of Franklin and Paxinos (2001). The observed patterns of GFP expression are outlined in Figure 2 and supplemental Table 1 (available at www.jneurosci.org) and discussed in greater detail below. WT mouse brain tissue demonstrated no immunoreactivity for the GFP antiserum that was used.

\section{Cerebral cortex and cerebellum}

GFP-IR cells were distributed preferentially in layer 5, although several cortical areas, including the insular, perirhinal, and visual cortices, revealed multilayer expression patterns of GFP (Figs. $2 A-H, 4 B$; supplemental Table 1, available at www.jneurosci. org). The immunoreactivity was most intense in the olfactory tubercle within the cerebral cortex (Fig. $2 A, B$ ). GFP-IR cells in layer 1 were very few throughout the cerebral cortex. In the cerebellum, only a few GFP-IR cells were localized in the medial cerebellar nucleus.

\section{Striatum}

In the nucleus accumbens, small numbers of GFP-positive cells were distributed in the shell (Fig. 2B). Small numbers of GFP-IR cells were present in the caudate-putamen $(\mathrm{Cpu})$, mainly in its ventral portion (Fig. $2 C-F$ ). Whereas the lateral globus pallidus (GP) contained no GFP-IR cells, weak labeling was seen in the medial GP (Fig. 2 F). The substantia inominata and ventral pallidum showed moderate labeling (Fig. 2B-E).

\section{Septum and hippocampal formation}

The lateral septal nucleus exhibited low to moderate levels of GFP expression, which were higher in the dorsal and intermediate parts than in the ventral part (Fig. $2 B, C$ ). GFP-IR cells in the medial septal nucleus were very few. Numerous labeled cells were distributed in the full longitudinal extent of the hippocampal formation (Fig. 2E-H). The Ammon's horn demonstrated GFP expression localized in the pyramidal layer, and the immunoreactivity was most prominent in field CA1. The dentate gyrus exhibited moderate labeling mainly in the granular layer and additionally in the polymorphic layer. The subiculum also contained a large number of GFP-IR cells in its ventral and intermediate parts (Fig. 4E) (Kishi et al., 2000).

\section{Amygdala and bed nucleus of the stria terminalis (BST)}

Within the amygdala and extended amygdala, the nucleus of the lateral olfactory tract was one of the structures that displayed highest levels of GFP immunoreactivity (Fig. 2D). In this nucleus, labeled cells were clustered in layers 2 and 3 but not in layer 1. The medial amygdaloid nucleus contained many GFP-IR cells (Fig. $2 E-H$ ), and more labeled cells were populated in more caudal portions (Fig. $2 \mathrm{H}$ ). Moderate levels of GFP immunoreactivity were observed in the medial division of the central amygdaloid nucleus (CeA), whereas the lateral and capsular CeA divisions tended to be devoid of labeling (Figs. 2E-G, 5I,M). The basolateral amygdaloid nucleus contained a moderate number of GFP-IR cells, predominantly in the anterior division of this nucleus (Fig. 2D-F). In the lateral nucleus, a few labeled cells were present in the lateralmost portion (Fig. $2 F, G$ ). The BST showed low levels of GFP immunoreactivity throughout its entire extent (Fig. 2C), with an exception of moderate labeling in the posteromedial subnucleus of the medial division.

\section{Thalamus}

Only a few thalamic nuclei were labeled. The nucleus reuniens showed high levels of GFP expression (Fig. 2D-G); however, labeling was weak in this nucleus in one of the four mice examined. Low to moderate labeling was present in the reticular, lateral habenular (Fig. $2 \mathrm{~F}-\mathrm{H}$ ), and ventromedial nuclei. Moderate numbers of GFP-positive cells were distributed in the caudodorsal portion of the zona incerta (Fig. $2 \mathrm{H}$ ). In the lateral genic-

\footnotetext{
(Figure legend continued.) nucleus; IRt, intermediate reticular nucleus; LA, lateral nucleus of the amygdala; LC, locus coeruleus; LDT, laterodorsal tegmental nucleus; LEnt, lateral entorhinal cortex; LHA, lateral hypothalamic area; LHb, lateral habenular nucleus; Im, lateral magnocellular division of the PVH; LOT, nucleus of the lateral olfactory tract; LSN, lateral septal nucleus; Iv, lateral ventricle; MdRt, medullary reticular nucleus; MeA, medial nucleus of the amygdala; mm, medial magnocellular division of the PVH; MnR, median raphe; Mo, motor cortex; Mo5, motor trigeminal nucleus; mp, medial parvicellular division of the PVH; MPO, medial preoptic nucleus; MPT, medial pretectal nucleus; MVe, medial vestibular nucleus; NTS, nucleus of the solitary tract; ot, optic tract; PAG, periaqueductal gray; PBel, parabrachial nucleus, external lateral; PBil, parabrachial nucleus, internal lateral; PBsl, parabrachial nucleus, superior lateral; PCRt, parvicellular reticular nucleus; PFA, perifornical area; Pir, piriform cortex; PLC o, posterolateral cortical nucleus of the amygdala; PMR, paramedian raphe; PnRt, pontine reticular nucleus; PPT, pedunculopontine tegmental nucleus; PRh, perirhinal cortex; PVH, paraventricular nucleus of the hypothalamus; $\mathrm{Py}$, pyramidal tract; Re, nucleus reuniens of the thalamus; RMg, raphe magnus; RPa, raphe pallidus; $\mathrm{SC}$, superior colliculus; scp, superior cerebellar peduncle; SF0, subfornical organ; SP5, spinal trigeminal nucleus; Sv, ventral subiculum; SS, somatosensory cortex; Tu, olfactory tubercle; VLG, ventral geniculate nucleus; VMH, ventromedial hypothalamic nucleus; VMPO, ventromedial preoptic nucleus; VP, ventral pallidum; Zl, zona incerta; $3 \mathrm{v}$, third ventricle; $4 \mathrm{v}$, fourth ventricle; 12 , hypoglossal nucleus.
} 
ulate nucleus, labeled cells were observed exclusively in the ventral part (Fig. $2 H, I$ ).

\section{Hypothalamus}

There was an aggregation of many GFP-IR cells in the anteroventral periventricular nucleus (Fig. 2C). Labeling in the ventromedial preoptic nucleus was less intense (Fig. 2C,D). The medial preoptic and median preoptic nuclei contained only a few labeled cells. GFP immunoreactivity was undetectable in the suprachiasmatic and supraoptic nuclei. The PVH displayed a unique pattern of labeling (Fig. $2 E, F)$. Within the PVH, the density of GFP-IR cells was highest in the lateral half of the posterior division (Figs. $2 F, 5 \mathrm{~J}, N$ ). The anterior parvicellular division showed light labeling, whereas the medial magnocellular division also contained a moderate number of labeled cells. Only a few GFP-positive cells were also present in the lateral magnocellular division. On the other hand, the medial parvicellular division of the PVH was unlabelled.

In the tuberal hypothalamus, GFP immunoreactivity was evident in the DMH (Fig. 2G). The labeled cells were populated preferentially in the caudal portion of the ventral division of the $\mathrm{DMH}$, whereas labeling in the compact and dorsal $\mathrm{DMH}$ divisions was more intense in more rostral portions. GFP-positive cells were also present in an area closely dorsal to the DMH referred to as the dorsal hypothalamic area in the rat (Saper, 1995). The ventromedial nucleus (VMH) also displayed low to moderate labeling, which was denser in more dorsomedial portions of this nucleus (Fig. 2G,H). In addition, GFP-IR cells were observed to surround the ventrolateral surface of the VMH. Relatively small numbers of labeled cells were scattered in the lateral hypothalamic area (LHA), including the perifornical area (PFA) (Figs. $2 \mathrm{E}-\mathrm{H}, 5 \mathrm{~K}, \mathrm{O})$. The arcuate nucleus displayed a relatively low level of GFP immunoreactivity in the caudal one-third of this nucleus (Figs. $2 \mathrm{H}, 4 \mathrm{H}$ ). GFP-IR cells were also present in the most superficial layer of the median eminence.

\section{Midbrain, pons, and medulla oblongata}

Within the pretectal area, GFP expression was most prominent in the medial pretectal nucleus (Fig. 2I). The superior colliculus contained a large number of labeled cells, many of which were concentrated in the intermediate gray layer (Fig. $2 J, K$ ). The periaqueductal gray matter displayed moderate levels of labeling throughout its full rostral-to-caudal extent (Fig. $2 I-K$ ). In this columnar structure, labeling was most conspicuous in the ventrolateral division (Figs. $2 \mathrm{~K}, 4 \mathrm{~L}$ ). Intense labeling was evident in the dorsolateral portion of the interpeduncular nucleus (Fig. $2 J$ ). In the inferior colliculus, GFP-IR cells were distributed mainly in the medial portion of the external cortex (Fig. $2 L$ ). The pedunculopontine tegmental (Fig. $2 \mathrm{~K}$ ) and laterodorsal tegmental (Fig. $2 L$ ) nuclei exhibited moderate to high levels of GFP immunoreactivity.

The lateral parabrachial nucleus also displayed GFP expression, which was intense in the superior division, moderate in the dorsal and internal divisions, and weak in the central, external, and ventral divisions (Fig. $2 L$ ). Very few labeled cells were observed in the medial parabrachial nucleus. Whereas the paramedian raphe exhibited moderate levels of GFP immunoreactivity, fewer labeled cells were observed in the dorsal raphe, median raphe, raphe magnus, and raphe pallidus (Fig. $2 \mathrm{~K}, \mathrm{~N}, \mathrm{O}$ ). Moderate numbers of GFP-positive cells were scattered throughout the entire rostrocaudal and mediolateral extent of the nucleus of the solitary tract (Fig. $2 \mathrm{~N}, \mathrm{O}$ ). The dorsal motor nucleus of the vagus (Fig. $5 L, P$ ) and nucleus ambiguus contained moderate numbers of labeled cells (Fig. 2N,O). The hypoglossal nucleus showed moderate labeling (Fig. $2 \mathrm{~N}, \mathrm{O}$ ). Moderate to high levels of GFP immunoreactivity were observed in reticular nuclei including the pontine, parvicellular, gigantocellular, and the medullary nuclei (Fig. $2 \mathrm{~K}-\mathrm{O}$ ).

\section{Distribution of GFP-IR cells in line 30}

The distribution of GFP-IR cells in line 30 was nearly identical to that of line 21 with the following exceptions. In line 30, layer 1 of the cerebral cortex did not show GFP expression. GFP-IR cells were localized in layer 5 of the ectorhinal, perirhinal, and visual cortices in line 30. The dentate gyrus also revealed a discrepancy: GFP-IR cells were distributed in the polymorphic layer of line 30, whereas labeling was seen preferentially in the granular layer of line 21 . In line 30 , the nucleus accumbens and medial septum tended to contain more abundant GFP-positive cells. The ventromedial hypothalamic nucleus of line 30 contained very few GFP-IR cells. In line 30, GFP immunoreactivity was not detected in the median eminence and raphe pallidus.

\section{Distribution of MC4-R mRNA in WT mice}

As described, lines 21 and 30 of the MC4-R/GFP mice displayed nearly identical distribution patterns of GFP-IR cells. The patterns of GFP expression were almost identical to that of MC4-R mRNA in WT mice (Figs. 2-4), with only a few exceptions (supplemental Table 1, available at www.jneurosci.org). For example, the rostral portion of the medial parvicellular division of the $\mathrm{PVH}$ displayed weak MC4-R hybridization in WT mice (Figs. 3D, $4 F$ ), even though GFP-IR cells were not distributed in this PVH portion of both lines. MC4-R mRNA expression was observed in the raphe pallidus of the WT mice (Fig. $4 M$ ). As mentioned, however, GFP-positive cells were not distributed in this nucleus of line 30. In the WT mice, MC4-R mRNA was detected in multiple layers of the visual, ectorhinal, and perirhinal cortices, whereas GFP-IR cells were localized in layer 5 of these cortical fields in line 30. Conversely, the nucleus reuniens of both lines produced GFP, but MC4-R hybridization was undetectable in this thalamic nucleus of the WT mice. In line 30, the same discrepancy was observed in the polymorphic layer of the dentate gyrus.

In addition, the relative expression levels of MC4-R mRNA in the WT mice were highly consistent with those of GFP in each brain site of both lines. Control ISHH experiments demonstrated no MC4-R-specific hybridization.

\section{Colocalization of GFP and MC4-R mRNA}

A combination of ISHH and IHC revealed that nearly all GFP-IR cells coexpressed MC4-R mRNA in both lines of MC4-R/GFP mice. Representative examples of the colocalization in the medial division of the CeA, PVH, PFA, and in the dorsal motor nucleus of the vagus (DMV) are shown in Figure 5. However, in a small number of cases, GFP was expressed in sites where MC4-R mRNA was below the limit of detection. In line 21, for example, single-labeled GFP-positive cells were distributed in layer 1 of the cerebral cortex, medial cerebellar nucleus, and in the median eminence, although the WT mice did not display detectable MC4-R hybridization in these sites. Similarly, in line 30, the polymorphic layer of the dentate gyrus contained single-labeled GFP-IR cells, despite undetectable MC4-R hybridization in this layer of the WT mice. We cannot rule out that these few examples of discordance may represent ectopic expression of the transgene. However, it is important to note that in the vast majority of sites, the expression pattern was topographically identical to MC4-R mRNA in WT animals. Moreover, GFP-IR cells were found to coexpress MC4-R mRNA in nearly all of these sites. Taken to- 

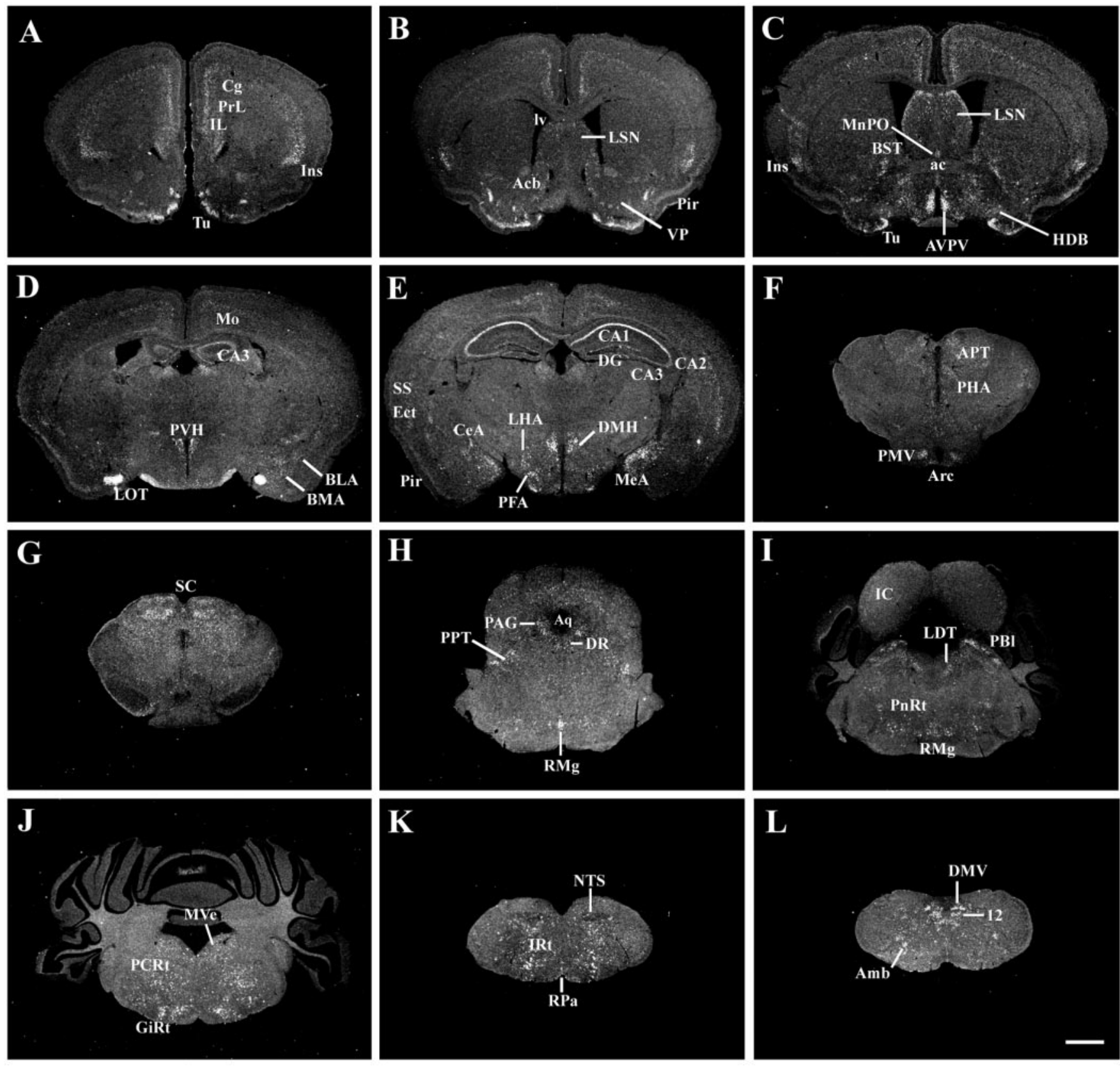

Figure 3. A series of low-power photomicrographs summarizing MC4-R mRNA expression sites across the WT mouse brain. Brain sections are arranged in a rostral-to-caudal manner ( $A-L)$. Scale bar (in $L), 1 \mathrm{~mm}(A-L)$. (For list of abbreviations, see Fig. 2 legend.)

gether, these findings demonstrate the usefulness of this mouse model in anatomic, molecular, and physiological studies.

\section{Chemical profiles of cells that produce GFP marker}

\section{for MC4-R}

To identify chemical phenotypes of MC4-R-positive cells in the brain sites involved in energy homeostasis, we performed a series of dual-label experiments, using line 21 of the MC4-R/GFP mice. The PVH contained cells coexpressing GFP and TRH mRNA (Fig. 6A, $B$ ). We also observed that a few GFP-IR cells producing GAD67 mRNA were scattered in the PFA (Fig. 6G-J), BST, CPu, and in the cerebral cortex.

In the DMV, GFP expression was observed in cells coexpressing ChAT mRNA (Fig. $6 K, L$ ), a marker for autonomic preganglionic neurons. The LHA including the PFA was observed to contain moderate numbers of GFP-IR cells as well as cells expressing ORX or MCH mRNA. However, we did not detect the colocalization of GFP and ORX mRNA or MCH mRNA.

Electrophysiological responses of GFP-expressing cells to a melanocortin receptor ligand

To determine whether MC4-R/GFP cells were able to respond directly to MC4-R agonists, electrophysiological patch-clamp recordings were performed on GFP-labeled neurons from line 21 mice. As mentioned, this line exhibited brighter GFP fluorescence. Wholecell current-clamp recordings were made from cells within the DMH and PVH of the hypothalamus (Fig. 7). As observed with other hypothalamic cells (our unpublished observations), MC4-R cells in the hypothalamus showed very high input resistance $(\geq 1 \mathrm{G} \Omega$ ) and fired action potentials spontaneously. To test the ability of MC4-R/GFP 

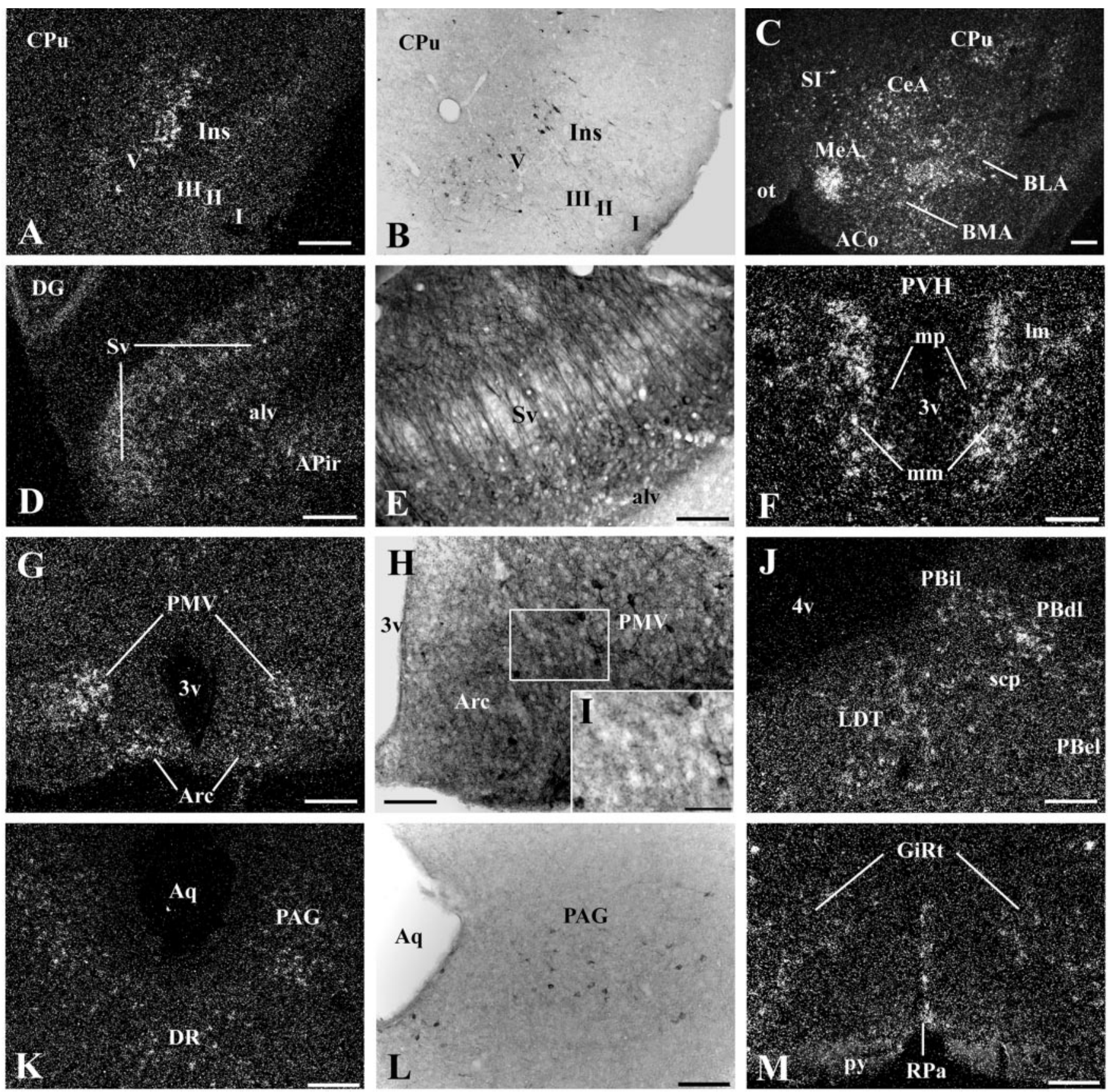

Figure 4. A series of high-power photomicrographs showing MC4-R mRNA in the WT mice and GFP-IR cells in the MC4-R/GFP mice (line 30). Note the consistency in the layer-specific pattern of MC4-R mRNA ( $A$ ) and GFP ( $B$ ) expression in the insular cortex (Ins). C, Widespread MC4-R hybridization in the amygdaloid complex. D, MC4-R mRNA expression in the pyramidal layer of the ventral subiculum (Sv). E, GFP-producing pyramidal Sv cells and their apical dendrites. F, MC4-R hybridization in the PVH, which is intense in the medial magnocellular division (mm) and light in the medial parvicellular (mp) and lateral magnocellular (Im) divisions. G, MC4-R mRNA expression in the Arc and ventral premammillary nucleus (PMV). H, GFP-IR Arc and PMV cells are embedded in a dense plexus of GFP-IR fibers and terminals. I, Higher-power magnification of a boxed area in $H$. J, K,M, MC4-R mRNA expression in the brain stem. Note the consistency of MC4-R mRNA and GFP ( $L$ ) expression in the ventrolateral part of the periaqueductal gray (PAG). $M, M C 4-R$ hybridization in the raphe pallidus (RPa) and gigantocellular reticular nucleus (GiRt). Scale bars: $A, C, D, G, J, K, M, 200$ $\mu \mathrm{m}$ (also applies to $B$ ); $E, F, H, L, 100 \mu \mathrm{m} ; I, 50 \mu \mathrm{m}$. (For list of abbreviations, see Fig. 2 legend.)

cells to respond to MC4-R agonists, slices were perfused with the MC3/4-R agonist, MTII, in the extracellular medium. MTII induced a significant depolarization of MC4-R/GFP cells $(2.47 \pm 1.17 \mathrm{mV}$; $n=14 ; p=0.028$ ). Despite this highly significant average effect, only six of the 14 cells that were tested showed a direct response to MTII. All of the responding neurons did respond similarly with a significant depolarization. The lack of effect in some cells would be seen in cases in which MC4-R is trafficked to presynaptic terminals because stimulation of presynaptic receptor would not be expected to have an effect on total cellular electrical activity. Whereas MTII is a nonspecific MC3/MC4-R agonist, the effect of MTII is likely to be mediated by MC4-Rs because MC3-Rs were not reported to be expressed in the DMH and PVH (Roselli-Rehfuss et al., 1993).

\section{Discussion}

In this study, we have generated a transgenic mouse-expressing GFP under the control of the MC4-R promoter (MC4-R/GFP 

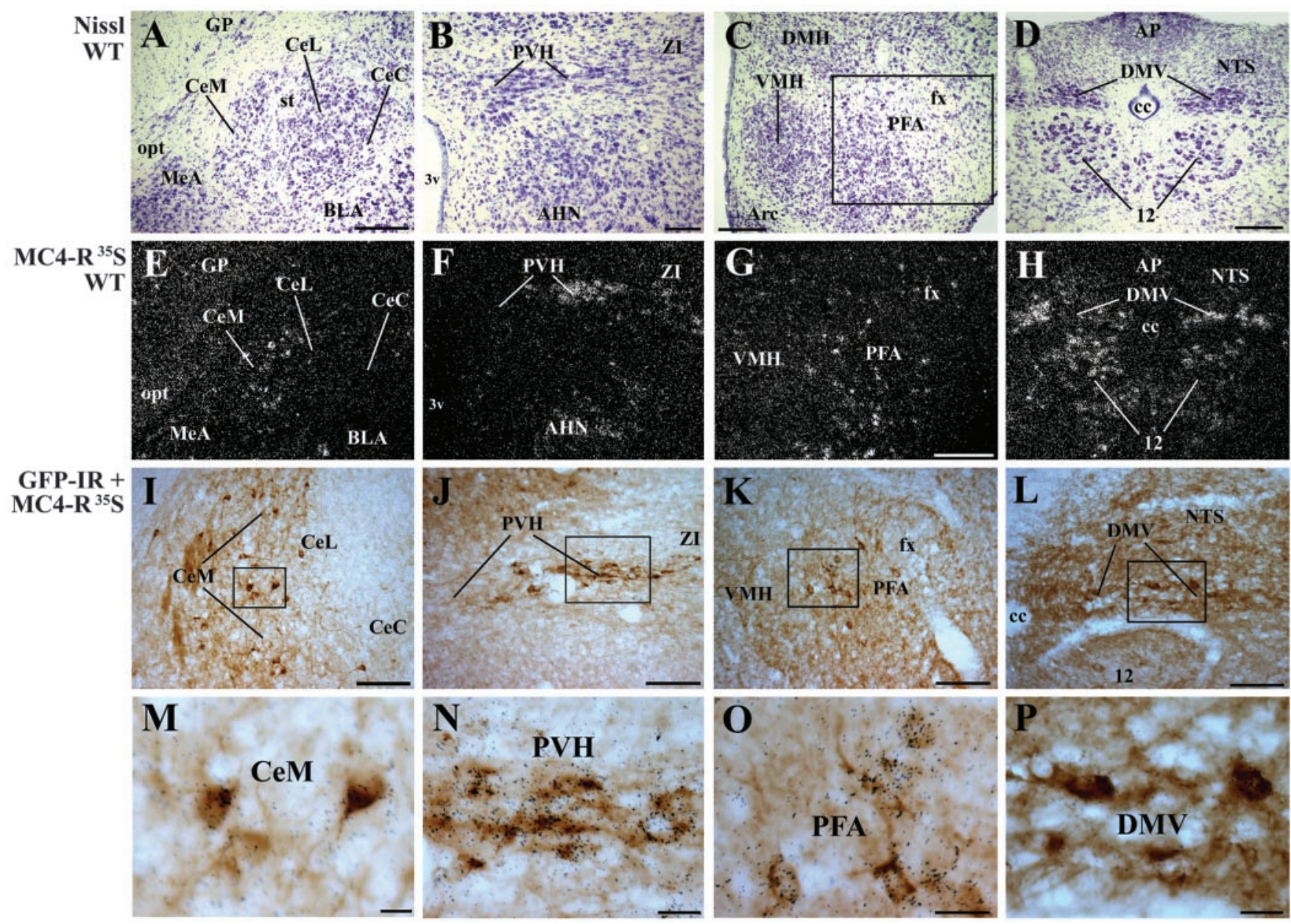

Figure 5. Colocalization of GFP and MC4-RmRNA in the MC4-R/GFP mice (line 21). A-D, Niss--stained brain sections of the wild-type mouse (WT). E-H, Adjacent sections of the brain shown in $A, B, C$ (boxed area), and $D$, respectively, showing MC4-R mRNA expression. $I-L$, Cells coexpressing GFP and MC4-R mRNA in the central amygdaloid nucleus medial division (CeM), PVH, PFA, and DMV, respectively. M-P, Higher-power magnification of boxed areas in $I, J$, $K$, and $L$, respectively. The cells containing clusters of grains were hybridized with an MC4-R ${ }^{35} S$-labeled probe. The GFP-IR cells contain brown cytoplasmic reaction product. Scale bars: $A, 200 \mu \mathrm{m}$ (also applied to $200 \mu \mathrm{m}$ in $E$ ); $B, 100 \mu \mathrm{m}$ (also applied to $F$ ); $C, D, 200 \mu \mathrm{m}$ (also applied to H); G, $200 \mu \mathrm{m} ; /-K, 100 \mu \mathrm{m} ; M-P, 20 \mu \mathrm{m}$.

mouse). We have confirmed that the distribution of GFP-IR cells is almost identical to that of MC4-R mRNA in the WT mice and that nearly all GFP-IR cells coexpress MC4-R mRNA. In addition, the MC4-R/GFP mice allowed us to readily determine chemical profiles of MC4-R-positive cells. Finally, we have observed that a synthetic MC3/4-R agonist, MT-II, depolarizes a subset of GFP-positive hypothalamic cells.

\section{Technical considerations}

In this study, we chose to use a MC4-R BAC to induce GFP expression under the control of the MC4-R promoter in the transgenic mice. Plasmid vectors carry up to $20 \mathrm{~kb}$ genomic DNA, whereas BACs can carry $>120 \mathrm{~kb}$ genomic sequence. Thus, a BAC is more likely to contain critical regulatory elements of a gene necessary for the faithful expression of the given gene. Our MC4-R/GFP BAC contained $50 \mathrm{~kb} 5^{\prime}$ sequence and $95 \mathrm{~kb} 3^{\prime}$ sequence to the Tau-GFP-polyA insertion site, which were sufficient to ensure relatively faithful expression of GFP. Nonetheless, the site of BAC insertion into the mouse chromosomes can still have an impact on the distribution of the marker gene, as evidenced by small differences in the GFP expression patterns in line 21 and line 30. These data would indicate that careful analyses of multiple transgenic lines are required to ensure faithful expression of the inserted gene.
To confirm correct GFP expression, we used a combination of ISHH and IHC. As in all ISHH studies, it is possible that our duallabel method is not sensitive enough to detect MC4-R mRNA. However, we observed that nearly all GFP-IR cells coexpressed MC4-R mRNA. Combined with the electrophysiological responses of GFPexpressing cells to MT-II, this observation indicates that the GFP expression is eutopic and, thus, validates this mouse model.

Another issue inherent in the BAC targeting method is that a modified BAC may contain sequences from neighboring genes that can in principle be overexpressed in the transgenic mice. However, we did not observe any phenotype in our mice besides the expression of GFP (our unpublished observations).

\section{MC4-R mRNA expression in WT mice}

This study also provides novel findings regarding the distribution of MC4-R mRNA in WT mice. In general, the CNS distribution of MC4-R mRNA in the WT mice was analogous to that of the rat (Mountjoy et al., 1994; Kishi et al., 2003), with a few exceptions. For example, intense MC4-R hybridization was evident in hippocampal CA1-3 fields of the WT mice, whereas these fields of rats contain a small number of cells expressing low to moderate levels of MC4-R mRNA. Whereas the WT mouse brain exhibited faint MC4-R hybridization in the $\mathrm{CPu}$, the rat $\mathrm{CPu}$ expresses high levels of MC4-R mRNA. The vestibular nucleus of the WT mice, 
but not of rats, expresses MC4-R mRNA. These discrepancies are likely viewed as species differences. Regardless, the patterns of MC4-R mRNA expression are similar to those of $\alpha$-MSH and AgRP axons in mice (Broberger et al., 1998b). In mice, for example, melanocortin axons are distributed in the PVH, LHA, and the DMV (Broberger et al., 1998b), all of which are deeply implicated in energy homeostasis (for review, see Elmquist et al., 1999; Grill and Kaplan, 2002). Because projections from these mouse brain sites are largely unknown, retrograde tracing in the MC4-R/GFP mice will facilitate this important line of investigation.

\section{Chemical profiles of MC4-R/GFP cells}

Our BAC transgenic line provides an opportunity to establish which neurotransmitters and neuropetides are colocalized with MC4-Rs (and which are not). In this study, we identified a subset of GFP-IR PVH cells coexpressing TRH mRNA (Fig. 6A,B). This finding agrees well with our previous observation that the rat $\mathrm{PVH}$ contains cells coexpressing MC4-R and TRH mRNAs (Harris et al., 2001). Similarly, we observed GFP-IR cells coexpressing ChAT mRNA in the DMV (Fig. 6K,L) and recently reported MC4-R mRNA expression in cholinergic DMV cells (i.e., parasympathetic preganglionic neurons) in the rat (Kishi et al., 2003). In considering a dense plexus of melanocortin axons in the mouse PVH (Broberger et al., 1998b), hypophysiotropic TRH neurons coexpressing MC4-Rs may mediate leptin action to regulate the thyroid axis (Legradi et al., 1998; Fekete et al., 2000; Harris et al., 2001). Because parasympathetic preganglionic DMV neurons regulate pancreatic $\beta$-cell function, the lack or blockade of MC4-Rs in this nucleus may contribute to the hyperinsulinemia in MC4- $\mathrm{R}-/-$ mice

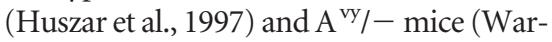
britton et al., 1994). This possibility can be further evaluated using our BAC transgenic mice to analyze whether GFP-producing DMV cells project to postganglionic neurons innervating the pancreas.

Sympathetic regulation is a major component of central melanocortin action (for review, see Elmquist, 2001; Saper et al., 2002). Evidence suggests that the PVH relays leptin signaling from the arcuate nucleus to MC4-Rs in the PVH. The dorsal, ventral, and lateral parvicellular divisions of the rat PVH contain neurons producing oxytocin or AVP and innervate sympathetic preganglionic neurons in the spinal cord (Cechetto and Saper, 1988). These rat PVH divisions express MC4-R mRNA (Mountjoy et al., 1994; Kishi et al., 2003) and receive melanocortin inputs from the Arc, some of which are leptin responsive (T. Kishi and J. K. Elmquist, unpublished observations). The mouse PVH is also innervated by $\alpha$-MSH and AgRP neurons (Broberger et al., 1998b). We, therefore, assessed whether PVH cells producing oxy-
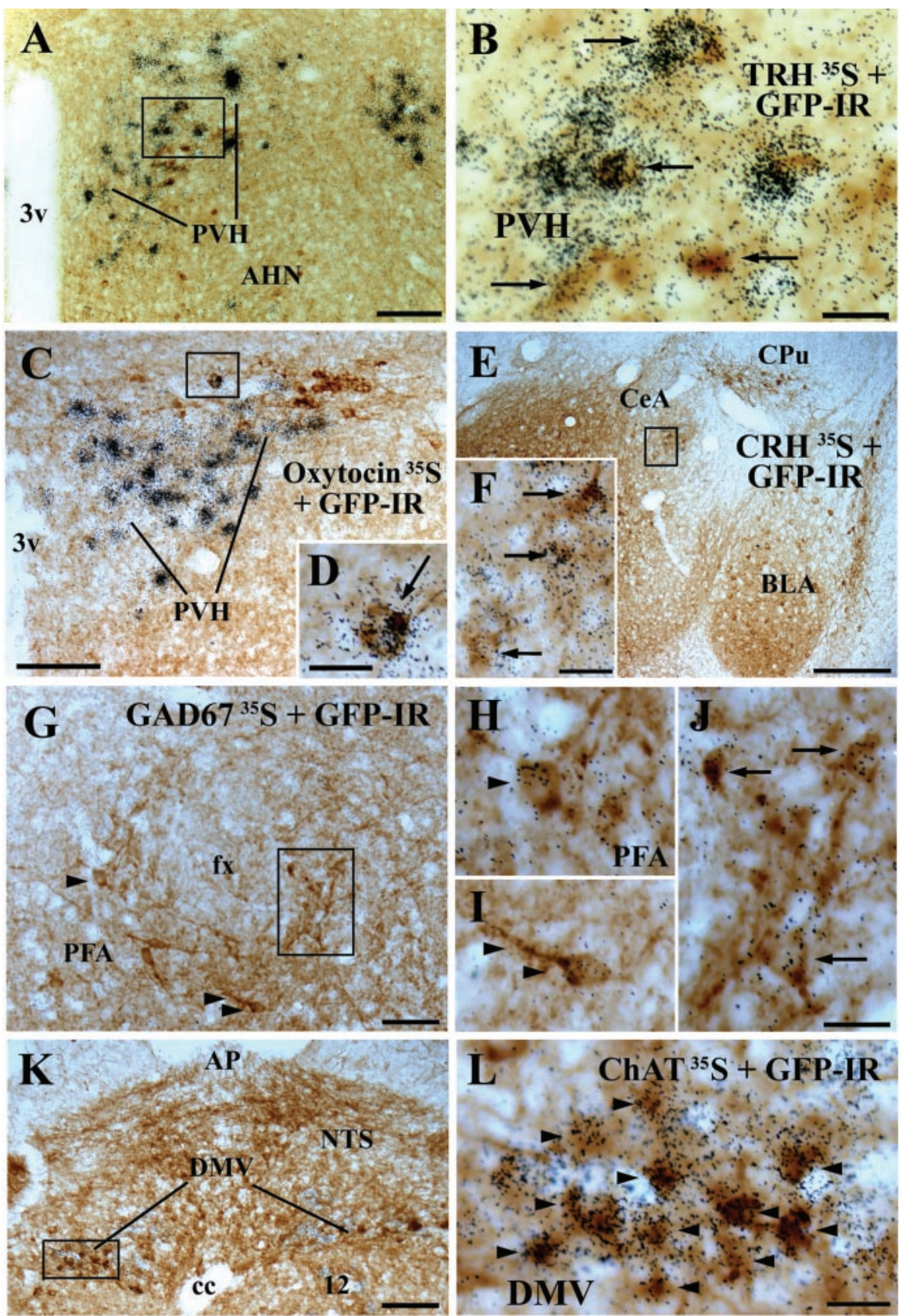

Figure 6. A series of photomicrographs showing chemical profiles of MC4-R/GFP cells. The GFP-IR cells contain brown cytoplasmic reaction product. The cells containing clusters of grains were hybridized with a ${ }^{35} \mathrm{~S}$-labeled probe for TRH in the PVH $(A, B)$, oxytocin in the PVH (CD), CRH in the central amygdaloid nucleus medial division (CeM) $(E, F)$, GAD67 in the PFA (G-J), or ChA mRNA $(K, L)$. Boxed areas in $A, C, E, G, K$ are magnified in $B, D, F, J$, and $L$, respectively. A cell indicated by an arrowhead and another cell by two arrowheads in $G$ are magnified in $H$ and I, respectively. Arrows and arrowheads indicate double-labeled cells. Scale bars: $A, C, K, 100 \mu \mathrm{m} ; E, 200 \mu \mathrm{m} ; B, D, F, H-J, L, 20 \mu \mathrm{m} ; G, 50 \mu \mathrm{m}$.

tocin or AVP also express MC4-Rs. However, we observed only a few GFP-IR cells coexpressing oxytocin mRNA and no GFP-IR cells coexpressing AVP mRNA in this nucleus. Notably, the posterolateral PVH, in which GFP-IR cells are densely packed, did not show any expression of oxytocin, AVP, TRH, or CRH mRNA. Because the lateral parvicellular division of the rat $\mathrm{PVH}$ expresses high levels of MC4-R mRNA (Mountjoy et al., 1994; Kishi et al., 2003) and contains neurons projecting to autonomic preganglionic neuronal populations (for review, see Saper, 1995), it is possible that previously unidentified types of cells may relay melanocortin signals to regulate autonomic function via the PVH. As noted, there is a striking lack of 


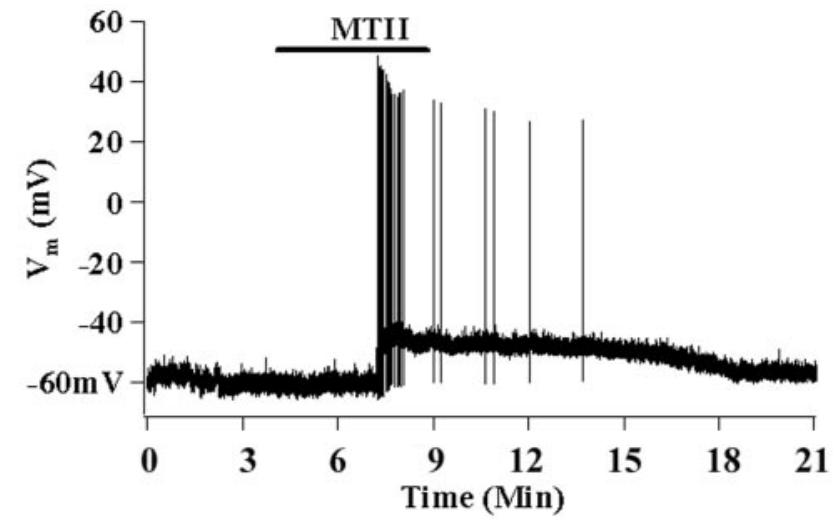

Figure 7. MTII depolarized MC4-R/GFP neurons in a hypothalamic slice preparation. Wholecell recordings were performed on MC4-R/GFP neurons held in current clamp. A sample recording from an MC4-R neuron treated with $100 \mathrm{~nm} \mathrm{MTIl}$ is shown. Mean effect: $2.47 \pm 1.17 \mathrm{mV}$; $n=14 ; p=0.028$.

tract-tracing data in the mouse, and, thus, it is also possible that the chemical neuroanatomy of mouse hypothalamic neurons innervating autonomic preganglionic neurons may be different from that of the rat. The MC4-R/GFP BAC transgenic mice will greatly facilitate future studies to determine the cellular phenotype of MC4-Rexpressing neurons in the mouse posterolateral PVH and their projections to autonomic centers and elsewhere.

The present data also have important implications regarding the possible role of melanocortin signaling through the LHA. The LHA contains two distinct neuronal populations producing $\mathrm{MCH}$ (Bittencourt et al., 1992) or ORX (Sakurai et al., 1998), both of which have been suggested to be orexigenic (Qu et al., 1996; Sakurai et al., 1998; Shimada et al., 1998). In addition, $\alpha$-MSH and AgRP neurons in the Arc, most of which are leptin responsive (Elias et al., 1999), provide dense inputs to the LHA (Broberger et al., 1998a; Elias et al., 1998). These observations have led to an expectation that $\mathrm{MCH}$ neurons and/or ORX neurons expressing MC4-Rs may be downstream targets of leptin (for review, see Sawchenko, 1998; Elmquist et al., 1999). However, we failed to detect GFP-IR cells coexpressing $\mathrm{MCH}$ or ORX, even though radioisotopic ISHH demonstrated a number of MCH and ORX cells in the LHA. In line with this finding, we have recently reported that levels of MC4-R mRNA expression are very low in the rat LHA (Kishi et al., 2003). Thus, it is plausible that melanocortins may act presynaptically on MC4-Rs expressed on axon terminals arising from certain CNS sites projecting to the LHA. Another possibility is that melanocortins act on MC3-Rs in the LHA.

In support of the first possibility, a previous electrophysiological study has shown that $\alpha$-MSH can act presynaptically on MC4-Rs expressed on axon terminals of GABAergic neurons (Cowley et al., 1999). Brain sites containing PVH-projecting GABAergic neurons include the BST (Cullinan et al., 1993) and PFA (Roland and Sawchenko, 1993; Boudaba et al., 1996). Recently, we reported MC4-R mRNA expression in the BST and PFA in the rat (Kishi et al., 2003). Notably, in the MC4-R/GFP mice, we found cells coexpressing GFP and GAD67 mRNA in the BST and PFA (Fig. 6G). It is, thus, possible that GABAergic inputs to the PVH emanate from melanocortinergic neurons in the BST and/or PFA.

In summary, we have generated a BAC transgenic mouse line that faithfully expresses GFP in MC4-R-expressing cells. We have used this line to extend our knowledge of chemical phenotypes and electrophysiological responses of MC4-R-expressing cells. Future studies using the MC4-R/GFP mice are likely to contribute to our under- standing of neural bases underlying energy balance and leptin action. The present study also confirms that the BAC transgenic methodology can be successfully used to mark specific cell types harboring genes that are not abundantly expressed.

\section{References}

Bittencourt JC, Presse F, Arias C, Peto C, Vaughan J, Nahon JL, Vale W, Sawchenko PE (1992) The melanin concentrating hormone system of the rat brain: an immuno- and hybridization histochemical characterization. J Comp Neurol 319:218-245.

Boston BA, Blaydon KM, Varnerin J, Cone RD (1997) Independent and additive effects of central POMC and leptin pathways on murine obesity. Science 278:1641-1644.

Boudaba C, Szabo K, Tasker JG (1996) Physiological mapping of local inhibitory inputs to the hypothalamic paraventricular nucleus. J Neurosci 16:7151-7160.

Brady LS, Lynn AB, Herkenham M, Gottesfeld Z (1994) Systemic interleukin-1 induces early and late patterns of $\mathrm{c}$-fos mRNA expression in brain. J Neurosci 14:4951-4964.

Broberger C, Lecea LD, Sutcliffe JG, Hökfelt T (1998a) Hypocretin/orexinand melanin-concentrating hormone-expressing cells form distinct populations in the rodent lateral hypothalamus: relationship to the neuropeptide $\mathrm{Y}$ and agouti gene-related protein systems. J Comp Neurol 402:460-474.

Broberger C, Johansen J, Johansson C, Schalling M, Hökfelt T (1998b) The neuropeptide Y/agouti gene-related protein (AGRP) brain circuitry in normal, anorectic, and monosodium glutamate-treated mice. Proc Natl Acad Sci USA 95:15043-15048.

Butler AA, Cone RD (2002) The melanocortin receptors: lessons from knockout models. Neuropeptides 36:77-84.

Butler AA, Marks DL, Fan W, Kuhn CM, Bartolome M, Cone RD (2001) Melanocortin-4 receptor is required for acute homeostatic responses to increased dietary fat. Nat Neurosci 4:605-611.

Callahan CA, Thomas JB (1994) Tau- $\beta$-galactosidase, an axon-targeted fusion protein. Proc Natl Acad Sci USA 91:5972-5976.

Cechetto DF, Saper CB (1988) Neurochemical organization of the hypothalamic projection to the spinal cord in the rat. J Comp Neurol 272:579-604.

Chan RK, Brown ER, Ericsson A, Kovacs KJ, Sawchenko PE (1993) A comparison of two immediately-early genes, c-fos and NGFI-B, as markers for functional activation in stress-related neuroendocrine circuitry. J Neurosci 13:5126-5138.

Cheung CC, Clifton DK, Steiner RA (1997) Proopiomelanocortin neurons are direct targets for leptin in the hypothalamus. Endocrinology 138:4489-4492.

Cowley MA, Pronchuk N, Fan W, Dinulescu DM, Colmers WF, Cone RD (1999) Integration of NPY, AgRp, and melanocortin signals in the hypothalamic paraventricular nucleus: evidence of a cellular basis for the adipostat. Neuron 24:155-163.

Cullinan WE, Herman JP, Watson SJ (1993) Ventral subicular interaction with the hypothalamic paraventricular nucleus: evidence for a relay in the bed nucleus of the stria terminalis. J Comp Neurol 332:1-20.

Day HEW, Vittoz NM, Oates MM, Badiani A, Watson SJ, Robinson TE, Akil H (2002) A 6-hydroxydopamine lesion of the mesostriatal dopamine system decreases the expression of corticotropin releasing hormone and neurotensin mRNAs in the amygdala and bed nucleus of the stria terminalis. Brain Res 945:151-159.

Elias CF, Saper CB, Maratos-Flier E, Tritos NA, Lee C, Kelly J, Tatro JB, Hoffman GE, Ollmann MM, Barsh GS, Sakurai T, Yanagisawa M, Elmquist JK (1998) Chemically defined projections linking the mediobasal hypothalamus and the lateral hypothalamic area. J Comp Neurol 402:442-459.

Elias CF, Aschkenasi C, Lee C, Kelly J, Ahima RS, Bjoorbaek C, Flier JS, Saper CB, Elmquist JK (1999) Leptin differentially regulates NPY and POMC neurons projecting to the lateral hypothalamic area. Neuron 23:775-786.

Elmquist JK (2001) Hypothalamic pathways underlying the endocrine, autonomic, and behavioral effects of leptin. Int J Obes Relat Metab Disord [Suppl 5]:S78-S82.

Elmquist JK, Saper CB (1996) Activation of neurons projecting to the paraventricular hypothalamic nucleus by intravenous lipopolysaccharide. J Comp Neurol 374:315-331.

Elmquist JK, Bjoorbaek C, Ahima RS, Flier JS, Saper CB (1998) Distributions of leptin receptor mRNA isoforms in the rat brain. J Comp Neurol 395:535-547. 
Elmquist JK, Elias CF, Saper CB (1999) From lesions to leptin: hypothalamic control of food intake and body weight. Neuron 22:221-232.

Ericsson A, Liu C, Hart RP, Sawchenko PE (1995) Type-1 interleukin-1 receptor in the rat brain: distribution, regulation, and relationship to sites of IL-1-induced cellular activation. J Comp Neurol 361:681-698.

Erlander MG, Tillakarante NJ, Feldblum S, Patel N, Tobin AJ (1991) Two genes encode distinct glutamate decarboxylase. Neuron 7:91-100.

Fan W, Boston BA, Kesterson RA, Hruby VJ, Cone RD (1997) Role of melanocortinergic neurons in feeding and the agouti obesity syndrome. Nature 385:165-168.

Farooqi IS, Yeo GS, Keogh JM, Aminian S, Jebb SA, Butler G, Cheetham T, O'Rahilly S (2000) Dominant and recessive inheritance of morbid obesity associated with melanocortin 4 receptor deficiency. J Clin Invest 106:271-279.

Fekete C, Légrádi G, Mihály E, Huang Q-H, Tatro JB, Rand WM, Emerson $\mathrm{CH}$, Lechan RM (2000) $\alpha$-Melanocyte-stimulating hormone is contained in nerve terminals innervating thyrotropin-releasing hormonesynthesizing neurons in the hypothalamic paraventricular nucleus and prevents fasting-induced suppression of prothyrotropin-releasing hormone gene expression. J Neurosci 20:1550-1558.

Franklin KBJ, Paxinos G (2001) The mouse brain in stereotaxic coordinates, Ed 2. San Diego: Academic.

Friedman JM, Halaas JL (1998) Leptin and the regulation of body weight in mammals. Nature 395:763-770.

Graham M, Shutter JR, Sarmiento U, Sarosi I, Stark KL (1997) Overexpression of Agrt leads to obesity in transgenic mice. Nat Genet 17:273-274.

Grill HJ, Kaplan JM (2002) The neuroanatomical axis for control of energy balance. Front Neuroendocrinol 23:2-40.

Hahn TM, Breininger JF, Baskin DG, Schwartz MW (1998) Coexpression of Agrp and NPY in fasting-activated hypothalamic neurons. Nat Neurosci 1:271-272.

Harris M, Aschkenasi C, Elias CF, Chandrankunnel A, Nillni EA, Bjoorbaek C, Elmquist JK, Flier JS, Hollenberg AN (2001) Transcriptional regulation of the thyrotropin-releasing hormone gene by leptin and melanocortin signaling. J Clin Invest 107:111-120.

Helmreich DL, Watkins LR, Deak T, Maier SF, Akil H, Watson SJ (1999) The effect of stressor controllability on stress-induced neuropeptide mRNA expression within the paraventricular nucleus of the hypothalamus. J Neuroendocrinol 11:121-128.

Huszar D, Lynch CA, Fairchild-Huntress V, Dunmore JH, Fang Q, Berkemeier LR, Gu W, Kesterson RA, Boston BA, Cone RD, Smith FJ, Campfield LA, Burn P, Lee F (1997) Targeted disruption of the melanocortin-4 receptor results in obesity in mice. Cell 88:131-141.

Kishi T, Tsumori T, Ono K, Yokota S, Ishino H, Yasui Y (2000) Topographical organization of projections from the subiculum to the hypothalamus in the rat. J Comp Neurol 419:205-222.

Kishi T, Aschkenasi CJ, Lee CE, Mountjoy KG, Saper CB, Elmquist JK (2003) Expression of melanocortin 4 receptor mRNA in the central nervous system of the rat. J Comp Neurol 457:213-235.

Kotz CM, Briggs JE, Pomonis JD, Grace MK, Levine AS, Billington CJ (1998) Neural site of leptin influence on neuropeptide Y signaling pathways altering feeding and uncoupling protein. Am J Physiol 275:R478-R484.

Krude H, Biebermann H, Luck W, Horn R, Brabant G, Grüters A (1998) Severe early-onset obesity, adrenal insufficiency and red hair pigmentation caused by POMC mutations in humans. Nat Genet 19:155-157.

Legradi G, Emerson CH, Ahima RS, Rand WM, Flier JS, Lechan RM (1998) Arcuate nucleus ablation prevents fasting-induced suppression of ProTRH mRNA in the hypothalamic paraventricular nucleus. Neuroendocrinology 68:89-97.

Marcus JN, Aschkenasi CJ, Lee CE, Chemelli RM, Saper CB, Yanagisawa M, Elmquist JK (2001) Differential expression of orexin receptors 1 and 2 in the rat brain. J Comp Neurol 435:6-25.

Mercer JG, Hoggard N, Williams LM, Lawrence CB, Hannah LT, Morgan PJ, Trayhurn P (1996) Coexpression of leptin receptor preproneuropeptide $\mathrm{Y}$ mRNA in arcuate nucleus of mouse hypothalamus. J Neuroendocrinol 8:733-735.

Mizuno TM, Kleopoulos SP, Bergen HT, Roberts JL, Priest CA, Mobbs CV (1998) Hypothalamic pro-opiomelanocortin mRNA is reduced by fasting in $\mathrm{ob} / \mathrm{ob}$ and $\mathrm{db} / \mathrm{db}$ mice, but is stimulated by leptin. Diabetes 47:294-297.

Mountjoy KG, Mortrud MT, Low MJ, Simerly RB, Cone RD (1994) Localization of the melanocortin-4 receptor (MC4-R) in neuroendocrine and autonomic control circuits in the brain. Mol Endocrinol 8:1298-1308.
Ollmann MM, Wilson BD, Yang Y-K, Kerns JA, Chen Y, Gantz I, Barsh GS (1997) Antagonism of central melanocortin receptors in vitro and in vivo by agouti-related protein. Science 278:135-138.

Priestley JV, Wotherspoon G, Savery D, Averill S, Rattray M (1993) A combined in situ hybridization and immunofluorescence procedure allowing visualisation of peptide mRNA and serotonin in single sections. J Neurosci Methods 48:99-110.

Qu D, Ludwig DS, Gammeltoft S, Piper M, Pelleymounter MA, Cullen MJ, Mathes WF, Przypek J, Kanarek R, Maratos-Flier E (1996) A role for melanin-concentrating hormone in the central regulation of feeding behaviour. Nature 380:243-247.

Roland BL, Sawchenko PE (1993) Local origins of some GABAergic projections to the paraventricular and supraoptic nuclei of the hypothalamus in the rat. J Comp Neurol 332:123-143.

Roselli-Rehfuss L, Mountjoy KG, Robbins LS, Mortrud MT, Low MJ, Tatro JB, Entwistle ML, Simerly RB, Cone RD (1993) Identification of a receptor for $\gamma$ melanotropin and other proopiomelanocortin peptides in the hypothalamus and limbic system. Proc Natl Acad Sci USA 90:8856-8860.

Sakurai T, Amemiya A, Ishii M, Matsuzaki I, Chemelli RM, Tanaka H, Williams SC, Richardson JA, Kozlowski GP, Wilson S, Arch JRS, Buckingham RE, Haynes AC, Carr SA, Annan RS, McNulty DE, Liu W-S, Terrett JA, Elshourbagy NA, Bergsma DJ, Yanagisawa M (1998) Orexins and orexin receptors: a family of hypothalamic neuropeptides and G proteincoupled receptors that regulate feeding behavior. Cell 92:573-585.

Saper CB (1995) Central autonomic system. In: The rat nervous system (Paxinos G, ed), pp 107-135. San Diego: Academic.

Saper CB, Chou TC, Elmquist JK (2002) The need to feed: homeostatic and hedonic control of eating. Neuron 36:199-211.

Satoh N, Ogawa Y, Katsuura G, Numata Y, Masuzaki H, Yoshimasa Y, Nakao K (1998) Satiety effect and sympathetic activation of leptin are mediated by hypothalamic melanocortin system. Neurosci Lett 249:107-110.

Sawchenko PE (1998) Toward a new neurobiology of energy balance, appetite, and obesity: the anatomists weigh in. J Comp Neurol 402:435-441.

Scarpace PJ, Matheny M, Pollock BH, Tumer N (1997) Leptin increases uncoupling protein expression and energy expenditure. Am J Physiol 273:E226-E230.

Schwartz MW, Seeley RJ, Woods SC, Weigle DS, Campfield LA, Burn P, Baskin DG (1997) Leptin increases hypothalamic pro-opiomelanocortin mRNA expression in the rostral arcuate nucleus. Diabetes 46:2119-2123.

Seeley RJ, Yagaloff KA, Fisher SL, Burn P, Thiele TE, van Dijk G, Baskin DG, Schwartz MW (1997) Melanocortin receptors in leptin effects. Nature 390:349.

Shimada M, Tritos N, Lowell BB, Flier JS, Maratos-Flier E (1998) Mice lacking melanin concentrating hormone are hypophagic and lean. Nature 396:670-674.

Simmons DM, Arriza JL, Swanson LW (1989) A complete protocol for in situ hybridization of messenger RNAs in brain and other tissues with radiolabelled single stranded RNA probes. J Histotechnol 12:169-181.

Spiegelman BM, Flier JS (1996) Adipogenesis and obesity: rounding out the big picture. Cell 87:377-389.

Thornton JE, Cheung CC, Clifton DK, Steiner RA (1997) Regulation of hypothalamic proopiomelanocortin mRNA by leptin in ob/ob mice. Endocrinology 138:5063-5066.

Vaisse C, Clement K, Guy-Grand B, Froguel P (1998) A frameshift mutation in human MC4R is associated with a dominant form of obesity. Nat Genet 20:113-114.

Warbritton A, Gill AM, Yen TT, Bucci T, Wolff GL (1994) Pancreatic islet cells in preobese yellow $\mathrm{A}^{\mathrm{vy}} / \mathrm{-}$ - mice: relation to adult hyperinsulinemia and obesity. Proc Soc Exp Biol Med 206:145-151.

Yamamoto H, Kishi T, Lee CE, Choi BJ, Fang H, Hollenberg AN, Drucker DJ, Elmquist JK (2003) Glucagon-like peptide-1 responsive catecholamine neurons in the area postrema link peripheral glucagon-like peptide-1 action with central autonomic control sites. J Neurosci 23:2939-2946.

Yang XW, Model P, Heintz N (1997) Homologous recombination based modification in Escherichia coli and germline transmission in transgenic mice of a bacterial artificial chromosome. Nat Biotechnol 15:859-866.

Yaswen L, Diehl N, Brennan MB, Hochgeschwender U (1999) Obesity in the mouse model of pro-opiomelanocortin deficiency responds to peripheral melanocortin. Nat Med 5:1066-1070.

Zhang Y, Proenca R, Maffei M, Barone M, Loepold L, Friedman JM (1994) Positional cloning of the mouse obese gene and its human homologue. Nature 372:425-432. 